\title{
Regional Policy and National Development in Korea
}

\author{
Soon Eun Kim*
}

\begin{abstract}
This paper analyzes regional and decentralization policy in Korea since 1970s. Each administration in the last 40 years has taken a distinctive approach to regional and decentralizaton policy. The 1970s and 1980s featured a highly centralized system that local administrations contributed to by following central directives and mandates, and the policies that emerged as a result of the Saemaeul movement were important in addressing rural poverty under the Park administration. During the 1990s under the Kim Young-sam and the Kim Daejung administrations, regional policy amounted to regional even-development, and decentralization policy came to underpin regional policy. The Noh administration was the most active in developing simultaneous regional even-development and decentralization policies. The Lee administration changed the equity-oriented direction of the regional policy pursued by the Noh administration to an efficiencyoriented one.

The regional policies discussed in this paper have been amended over time and in line with different political and economic circumstances in an attempt to generate relationships between the central government and local governments that will enable the country to achieve national goals in an efficient and effective way.
\end{abstract}

Key words: national development, regional policy, decentralization, local administration

\section{INTRODUCTION}

\section{Goals of This Study}

Given the particular situation in Korea, it can be said that regional economic policy refers to regional policy as such and regional democratic policy stands for decentralization and local autonomy. In addition, economic development has become deeply associated with regional even-development in light of the increasing economic disparity

\footnotetext{
* Soon Eun Kim is a professor in the Graduate School of Public Administration at Seoul National University Graduate School. E-mail: sekim0313@snu.ac.kr.
}

Manuscript received February 10, 2014; out for review March 3, 2014; review completed March 24, 2014; accepted March 26, 2014. 
between regions, in particular, between capital regions and noncapital regions. Regional democratic governance ultimately refers to local autonomy and decentralization, which have been included in the list of vital items for realizing democratic development since 1970s.

It is a general rule that to secure a democratic structure, political power should not be concentrated in a single institution. This dictum can be applied to the relationship between the central government and local governments. Decentralization is a reform process that distributes political power between the central government and local governments, favoring the latter, the belief being that decentralization ultimately leads to the smooth working of local autonomy. Further, decentralization works as a catalyst for improving a local government's ability to address local problems and to aptly respond to local needs and expectations (Kim, 2012a).

A purpose of this study is to examine the shift in regional policy goals between the 1970s and the present in Korea. Presumably, regional economic development can be sought at the expense of regional democracy under certain circumstances, while the latter can be pursued at the expense of the first under other circumstances. Ideally, however, it would be possible to achieve both aims harmoniously. This is a great challenge for developing countries in particular.

This study also aims to analyze the progress in issues of regional even-development, which constitutes regional policy, local autonomy, and decentralization. These issues are examined through four different time periods.

This study also attempts to show how the central government and local governments have transformed their relationships so as to effect national policies in an effective way. In a sense, the regional policies discussed in this paper, which were propelled by changes in national policies, served as a framework for establishing intergovernmental relations between the central government and local governments in Korea.

\section{Categorization of the Periods for Analyses}

There are four points in Korean political history at which the relationship between regional and decentralization policies shifted significantly.

The first is the era between 1970s and 1980s, during which the system of local autonomy had not yet been laid down completely. At this time, the national government directed local administration to carry out national regional policies and gave little discretion to it. The relationship between the national government and local administration was strictly hierarchical, the local administration being a mere administrative division of the national government.

The second is the period between 1991 and 2002, during which, under the auspices 
of local autonomy, local councils were elected and local chief executives were appointed and some central administrative functions began to be delegated to local governments after a time-consuming process of analyses and assessment by the Delegation Committee of Central Administrative Functions in consultation with relevant departments concerned (Hong, 2003). This was the first stage of local autonomy in Korea.

The third period coincides with Noh Moo-hyun's administration, which made tremendous efforts to put a variety of policies concerned with decentralization and regional even-development into effect between 2003 and 2007. They had been looked on as key national policies warranting top priority.

The fourth era falls within Lee Myung-bak's administration, which had undertaken a different policy from that of Noh's administration in relation to regional policy and decentralization, putting less emphasis on policy. The Lee administration intentionally began to use the word "regional development" instead of "regional even-development." Formerly, the strategy for regional development had been based on large-scale economic partnerships at the regional level (Kim, 2010a, 2010b, 2010c).

\section{THEORETICAL REVIEW OF REGIONAL POLICY}

\section{The Concept of Regional Policy}

The concept of region is vague. While the term as it is commonly used in international politics refers to a wider geographic area than the national territory, the region from a domestic perspective is defined as the territorial area that shares political, economic, social and cultural characteristics with the nation. Both the Scottish and the Welsh regions have a political identity that is distinct from that of the government of the UK but that nevertheless reflects the economic features of the UK. The adjective "regional" in regional governments in France includes political meaning, while in the phrase "regional development," it has an economic connotation. The region in a political view is not necessarily identical to that in an economic perspective.

This is the case in Korea, too. The term "regional" has been used in different ways under different presidents and in different contexts. For example, the term "regional" in "regional political emotion" in Korea refers to a wider area than the province, an upper tier of local government, while in "balanced regional economic policy," more often than not, the term indicates provinces. From a narrow perspective, in certain cases the region stands for smaller units than either a city or a county, such as regional community. In this study, "region" does not refer to areas smaller than the province because regional policies carried out by the national government since the 1970s have 
been targeted to geographic areas larger than the province.

In general, regional policy embraces a wide range of spheres stretching from regional development, transportation, tourism, culture, and education to local autonomy and decentralization (Assembly of European Regions, 2006). In Korea the term "regional policy" has more often referred to regional even-development (Korea Research Institute for Human Settlements, 2005) because the focus in Korea has been on addressing the development disparity among regions. As a result, this study is centered around regional even-development policy together with local autonomy and decentralization, which have been embraced to promote national development, because they have attracted considerable attention from many countries, in particular, developing countries, and they are closely associated with each other in the Korean context.

\section{Goals of Regional Policy}

As noted, the scope of regional policy is very wide, including economic development, transportation, telecommunication, leisure and sports, environment and energy, culture and education, housing, health, policing and justice. It can be said that there are two goals of regional policy underpinning the wide scope of regional policies: economic development and regional democratic governance.

The primary goal of regional policy is to promote economic development. Both past and contemporary regional policies in advanced countries and in developing countries as well have been oriented toward developing regions that are diverse in terms of size, population, geography, culture, and trade (Assembly of European Regions, 2006; Ueta \& Meitak, 2001). Two different policy options have been adopted toward this end. The first is the articulation on the part of the national government of various policies designed to improve regional economies. A typical example of this is policies that address industry location. Ultimately, this sort of policy is strongly associated with regional even-development policy. The second is a policy for making regional political identity stronger in the face of globalization, which has undermined the power of the national government to control economic affairs. This strategy is closely tied to the second goal of regional policy.

The second aim of regional policy is to improve regional democratic governance. Toward this aim, regional policies concerning regional democracy should consider some "basic tenets that should underpin the organization of all regional structures. These include proper legal status for regional body, the basis division of powers between a representative assembly and an executive body, the direct election of regional politicians and the free exercise of regional functions" (Assembly of European Regions, 2006, p. 14). Establishing regional democratic governance has been one of 
the key goals in European countries since 1990s.

Approaches to securing the two aims underlying the wide scope of regional policies take diverse forms that respond to the political and economic conditions in a given country. This is particularly the case in Korea. During certain periods one goal or the other was selectively highlighted and afterward modified. Quite recently considerable efforts have been made to achieve both goals simultaneously.

\section{ANALYSES OF REGIONAL POLICY OF KOREA}

\section{Regional Policy with Governmental Cohesion between the 1970s and 1980s}

Relationship between Regional Policy and Decentralization Policy. It is difficult to analyze the relationship between regional policy and decentralization policy during the period between 1970s and 1980s because the political and administrative systems were highly centralized and hierarchical. Decentralization during this period was practically nonexistent, as there were no local councils, and local chief executives were appointed by the central governments.

Local administrations in this period were very effective at effecting national policies with a variety of innovations (Whang, 1983). They were able to adequately carry out national policies with respect to regional economic development because highly qualified public officials who passed the highly competitive national entrance examination were dispatched to the local administrations on a rotating basis. In particular, local chief executives were transferred and promoted by the central government on the basis of a level of the performance of the national regional policies in their jurisdictions. The local administrations were able to save time that might have been spent in the process of discussing policy directions and avoid controversies they would have faced if there had been local councils. In a sense, the efficient and effective local administrative system during this period made a contribution to rapid regional economic development (Eom, 2011; Noh, 2013).

Regional Policy in 1970s and 1980s. Regional policies in the 1970s were characterized by multifaceted features: industry location policy, regulation policy of the Seoul capital region, and rural development policy (Kim, 2008; Park, 2009). The regional policy branded by industry location policy in the 1970s was not regional policy per se but an integral part of national economic policies. That is, national macroeconomic policy provided a framework for determining a sublevel regional policy.

The central government determined the location of heavy industries, including shipbuilding, automobile, electronics, petrochemicals, and steel. There was little possi- 
bility for local administration to be involved in and local voices to be heard in the process of locating industries because efficiency and effectiveness were the sole criteria on which central decisions of industry location were made, although a degree of political consideration figured in (Kim, 2008). The relationship between the central government and local administration with respect to industry location policy was hierarchical. Localities served as a mere administrative division of the state. The centrally designed industry location policy led to a concentration of the population in a few urban cities, in particular the capital regions, which resulted in regional disparity in various respects, including population and regional economic development (Kim, 2000).

When considering where to locate industries, the central government made a considerable effort to ensure balanced economic growth and to prevent overflow of migration from the rural area to the capital region by avoiding placing both major industries and small- and medium-size industries in the capital region. In addition, the central government persuaded industries and companies located in the capital region to shift to region outside the capital by offering a diversity of benefits and incentives.

At the same time, the central government introduced strategies to address population congestion and industry concentration problems that had plagued the capital region since 1960s by way of the capital regional planning and the Capital Region Readjustment Act (1982). The basic guidelines for mitigating the population congestion in the capital region by the Ministry of Construction were issued in 1970. In addition, the Ministry of Construction prepared the first comprehensive national development plan (1972-81) in 1970, which included policies geared toward the regulation of the capital region. In 1972 the presidential office issued the blueprint for dispersing the population of metropolitan cities. The Economic Planning Board subsequently released the policy for scattering the population of metropolitan cities in 1973 (Ministry of Construction and Transportation, 2006).

Despite the measures that were taken in the 1970s, the inflow of population into the capital region continued to increase. In the 1980s, the disparity in economic development between regions, in particular between the capital region and the region outside the capital, became ever more wide ranging, and the national government realized that it needed to adopt more far-reaching policies and administrative measures.

The Capital Region Readjustment Act in 1982 became a framework for controlling and monitoring the capital region. The heights of buildings, the range of land use, and the number of students who could be enrolled in the universities in the capital region were included in the list of items to be strictly regulated and restricted. The second comprehensive national development plan, in which regional even-development and social development were explicitly enshrined as regional policy goals, was prepared in 1982. This plan set out a clear framework for achieving balanced regional development. 
In addition, relocation of manufacturing industries and dispersal of government offices were highly recommended in the national plan (Kim, 2009).

At the same time, special attention was paid to poor and underdeveloped regions, which were mostly rural. In order to address the unbalanced development of rural areas, support policies and Saemaeul movement policy (SMP) were adopted. SMP demonstrates the significant role that local administrations in the 1970s played in national regional policy (Park, 2009).

Regional Policy and Local Administration. This study centers on local administrations between 1961 and 1991 that did not have directly elected local councils and whose annual budget and by-laws were established by the central government because local administrations made great contributions to the development of regions, in particular, the rural areas by way of playing a key role in the process of implementing. "Saemaeul Undong [movement $]^{1}$ was a community-based integrated rural development programme of the Republic of Korea in the 1970s which contributed to narrowing the developmental gap between urban cities and rural communities over a decade" (Park, 2009, p. 113). SMP has been assessed as a program that contributed considerably to the social and economic development of rural areas. It has been asserted that combination of factors, including appropriate strategies and timely measures (Park, 2009), strong political leadership (Noh, 2013), established regional governance (So, 2007), activities of local public officials (Eom, 2011), and innovations in local public administration (Whang, 1983) were factors that made the remarkable progress in rural development possible.

In particular, it has been argued that local administration's decisive role in forging and strengthening good governance in the 1970s contributed to the successful implementation of SMP (Kim, 2005; Eom, 2011), even though, as is well known, a hierarchical structure was in place that maintained vertical cohesion between the central government and local administrations.

Two approaches were adopted to implement SMP implementation: the top-down and the bottom-up approach. The central government initiated SMP to address the widening disparity in development between urban areas and rural areas that resulted from the selective industry location policy of the 1970s. The central government had also created a number of programs to increase rural people's income and reduce rural poverty. These included such undertakings as providing new agricultural technologies, improving physical infrastructure, and supplying the rural population with better sources for getting what was necessary for their activities (Park, 2009).

During this period the relationship between the central government and local

1. Author inserted. 
administration was hierarchical enough that it was possible to streamline local administrations, which was necessary for achieving national goals, that is, economic development. Directions and mandates related to the implementation of SMP were issued to the local administration by the central government, which took charge of coordinating the overall management of SMP. The central government maintained supervisory power over local administrations, which were legally bound to carry out the policy guidelines of SMP to the letter. The central government provided an effective mechanism for local administrations to carry out these directives by appointing state officials who had passed the highly competitive national examination to lead the local administrations. Local chief administrators with high profiles worked hard to make SMP successful in their jurisdiction because the outcome was a significant criterion in determining their personal career, including transfer and promotion. Centrally selected public officials could continue to carry out SMP independent of local vested interests (Park, 2009; Eom, 2011).

From a bottom-up perspective, local administrations played a major role in implementing SMP in a sustainable and effective way at the local level. To a limited extent local administrations were empowered to modify central directives on the basis of their local circumstances and situations (Eom, 2011). Local administrations also made local voices heard at the central level. Local administrations took great pains link local needs and preferences to central directives and mandates (So, 2009).

SMP local administrators also designed innovative solutions for dealing with issues related to the process of SMP implementation such as "(a) how to motivate the rural community people to work hard to improve living conditions, (b) how to get the community people to participate in planning and implementing self-help development projects, (c) how to effectively deliver government assistance and support to the community, and (d) how to effectively promote changes in community system" (Whang, 1983, p. 1).

Regional Policy and National Development. During this period the main goal of regional policies was to create an efficient system to implement national development policies for rapid economic growth. Toward this end, local government was handed the task of effecting national mandates and directives without local discretion. It can be argued that regional policies during this era contributed significantly to an effective and efficient national governmental system that worked as a vehicle for national development.

\section{Regional Policy with Local Autonomy between 1991 and 2002}

Relationship between Regional Policy and Decentralization Policy. The year 1991, 
in which a system of local autonomy was reestablished, is a meaningful point at which an investigation on the changing relationship between regional policy and decentralization policy in Korea began. For the first time, local councils were elected, although chief executives were still appointed by the national government. This change introduced a certain amount of political decentralization in Korea, and by 1995, local governments gained full political status when local chief executives too became elected officials. Owing to the introduction of full local elections in 1995, decentralization policy became, on a macro level, an integral part of the central regional policy(Kim, 1997).

Regional Policy in the 1990s. As a result of economic trends during this period, including market liberalization, the growth of postindustrial society, and the emergence of a knowledge-based economy, the imbalance in development between the capital region and the regions outside the capital and the difference between the urban and the rural regions had become far deeper and turned out to be a critical societal problem (Park, 2009; KRILA, 2013). Two presidents who had been outspoken opposition leaders in favor of democratization in Korea for decades, namely Kim Young-sam and Kim Dae-jung, adopted drastic regional policies in light of the trend in the 1990s characterized by an increasing regional economic gap.

The fundamental tenet underpinning regional policies in this period was reflected in the third comprehensive national development plan of 1992, whose goal was decentralization characterized by regional even-development. A strategy for building regional development centers was adopted. By concentrating public and private investment in the centers, which were intended to bridge regional center cities and their surrounding areas, it was hoped that a self-sufficient economic foundation based on adequate scales of economy could be established (Kim, 2000). That is, the main goal of the plan was to construct the economic foundation for regional even-development. In addition, the third comprehensive national development plan included strategies for developing lagging regions, in particular the west coast, by locating new industrial centers in them.

At the same time, the Kim Young-sam administration introduced very strict policies for controlling the capital region, such as "regulating firm location or economic activities, setting a ceiling on the number of firms in an area, levying a congestion charge, and introducing a differential tax, charge, and subsidy" (Park, 2009, p. 6). In addition, a policy to develop new districts was adopted under the leadership of President Kim Young-sam.

This package of policies for promoting lagging regions and for regulating the capital region, however, were judged not to have been so effective and successful. Even though the rate of population growth in the capital region decreased, the concentration in 
the capital regions persisted. To make matters worse, the Kim Young-sam administration was confronted with an economic crisis in 1997 that forced a restructuring of the national economy in Korea.

Due to the economic crisis in 1997 and subsequent emphasis on a knowledgebased emphasis economy, regional disparity gradually deepened. This was because the development investment required to produce advanced knowledge was primarily put into the capital region and the research was carried out there as well; as result of this most of the jobs related to knowledge-based industry were created there too.

In addressing the problem of the regional disparity, which manifested itself as a main policy objective of Kim Dae-jung, his administration maintained same position concerning regional even-development as that of his predecessor. The administration set up the Regional Even-Development Committee as a coordinating organization for dealing with regional gaps. This committee played a key role in conceiving, promoting, and facilitating the implementation of a variety of regional even-development policies (Park, 2009).

Nonetheless, the economic crisis in 1997 compelled the Kim Dae-jung administration to adopt policies that relaxed industry location regulation and that loosened greenbelt regulation. The former was designed to encourage foreign investment while the latter was intended to respond to regional needs. It was argued these measures had adverse impacts on regional even-development (Kim, 2009).

Regional Policy and Decentralization together with Local Autonomy. In the political atmosphere of decentralization, regional policies started to be conceived in combination with decentralization and local autonomy under the Kim Young-sam administration. President Kim succeeded in implementing political decentralization by setting up the local government system characterized by directly elected mayors and governors in 1995, which effected full-scale local autonomy (Kim, 2010a).

Elected local chief executives have played a very important role in regional development, bringing local demands and preferences to the table (Kim, 2005b). Unlike the appointed local chief executives, elected mayors and governors were able to act relatively independently of the central government. They not only served as catalysts for bottom-up regional development but also as channels through which local voices could be represented to the central government (Kim, 2000).

Elected local chief executives realized as they became active participants in regional development that local finances for executing local responsibilities were not sufficient enough to meet local needs. Due to this situation, local governments began to intensify their calls for decentralization(Kim, 2010a).

Eventually, the Kim Dae-jung administration satisfied local requests for decentralization reform by passing the Devolution Act in 1999. The basic principles and 
fundamentals of devolution reform were that "duplicate functions between the central government and local governments ought to devolve to local governments" and that "duplicate functions between upper-tier and lower-tier local governments ought to devolve to the lower-tier local governments." Further, "functions related to one another ought to be devolved in aggregate to local governments" and "functions assigned to the central government ought to be kept at such a minimum, restricted to generating country-wide policies and setting national standardization." The act also authorized the creation of a devolution commission whose task was to "facilitate the devolution of governmental functions to local governments" (Kim, 2010a, pp. 30-31). However, despite strenuous efforts on the part of the commission, the results were only sporadically successful, just like the Kim Dae-jung administration's regional even-development measures (Kim, 2004). The implementation of devolution and regional even- development were revisited as part of the next administration's agenda.

As a result of decentralization efforts, which gave local governments more power, the relationship between the central government and local governments became less hierarchical. Local governments started to make their voices heard in national policy making and in particular in policy implementation.

Regional Policy and National Development. This period was characterized by rising expectations for democracy, the achievement of which had been undermined by national policy geared toward economic development in the previous period. Promoting local democracy by granting local autonomy was regarded as an effective political tool for the peaceful transfer of power at the national level. In this sense, regional policy in this period deeply influenced democratic development in Korea.

\section{Regional Policy with Decentralization between 2003 and 2007}

Relationship between Regional Policy and Decentralization Policy. Ever since the late 1990s, the external policy environment has been characterized by globalization and localization (Kim, 2009; Park, 2009). Internally, regional even-development and decentralization were hot issues during the course of the presidential campaign in December 2002 (Kim, 2010a). The victory of the Democratic Party candidate, Noh Moo-hyun, in the 2002 presidential election paved the way for big changes because his administration provided a comprehensive framework for regional even-development, of which decentralization became an integral part (Kim, 2005b).

Regional Policy between 2003 and 2007. The drastic policy change in regional even- development was effected immediately after Noh's inauguration by the enactment of a special law for national even-development. This law provided for the establishment of a presidential committee to oversee national even-development. This committee 
sought to coordinate plans for regional even-development and thereby prevent traditional policy practices whereby each ministry embarked on initiatives without attempting to harmonize their plans with those of other ministries, practices that led to inefficient duplication and overlapping in budget allocation and also caused friction between governmental agencies (Kim, 2008). The committee also played a major role in designing action plans for attaining policy objectives and in monitoring progress.

The national even-development plan, which replaced the decennial comprehensive national development plans, was based on three policy challenges: regional imbalance in development, economic stagnation, and globalization (KRILA, 2005). To address these challenges, the Noh administration transformed regional policy in a drastic way, making it an integral part of national economic development policy. An endogenous bottom-up push for regional development was emphasized over top-down initiatives. As a result, the innovation capacity of and competition among regions became a major policy instrument through which policy goals could be attained in the course of seeking regional even-development (Kim, 2009).

The presidential committee adopted four strategies: "innovation-led regional development, development of rural communities in harmony with the development of urban communities, redirection of the development trajectory of the capital region and construction of network-structures territory in terms of functions and physical infrastructures" (KRIRA, 2005, p. 1). It also embraced three principles. "The first principle is a comprehensive approach, which means that the plan seeks for balanced development not by fragmented support but by comprehensive means such as decentralization and constructing a new administrative city. The second one is the construction of regional innovation system, which means that departing from traditional input-driven growth, the new system aims at autonomous localization building up regional innovation system and transform the regional economy into an innovation-driven one. The third one is developing non-capital regions first and then managing the Seoul capital area systematically, which is intended to develop both the capital and non-capital areas" (Kim, 2008, p. 8).

The Noh administration's regional even-development policy was divided into three parts: the dispersal of public agencies and offices and scattering of companies across the country, the promotion of regional innovative capacity, and decentralization. An attempt to construct a new administrative capital outside of Seoul, which was an integral part of Noh's presidential platform in December 2002, was controversial as a means for dispersing governmental offices and agencies. Once elected, Noh developed concrete action plans for setting up the administrative capital. An implementing body was created and a special measure legislating construction of the new administrative capital was passed on December 29, 2003. 
There was stiff opposition to the idea of a new administrative city from numerous quarters, including the opposition party, the mayor of Seoul and members of the Seoul City Council, and many NGOs located in Seoul (Kim, 2006). Eventually, a petition stating that the special measure was unconstitutional was brought to the constitutional court, which made a judgment in favor of the plaintiff. As a result, the new administrative capital, called Sejong, was scaled back (Kim, 2006), transformed into an upper-tier local government. The name Sejong was decided on the basis of the various suggestions by citizens.

One of the Noh administration's revolutionary ideas was to build 11 innovation cities to which all public corporations and public research institutes located in the capital regions would be relocated. More than 200 public corporations and public research institutes were supposed to be dispersed among the 11 innovation cities, each of which were to be situated in 11 different regions outside the capital region. The 11 innovation cities are under construction at this point. Initially, the construction was to be finished by the end of 2012 (Kim, 2009), but due to several reasons, including delays in the construction and the amount of time it took to sell the office buildings in the capital region, the public corporations and public research institutes will be moving to new cities later than scheduled.

At one point, another idea was to establish an enterprise city for private companies, but subsequently, the government decided instead to build a series of enterprise cities in underdeveloped regions among which private enterprises would be dispersed. The enterprise city is designed to be self-sufficient one that is not only friendly to private enterprises but also comfortable to live in. Six pilot cities were launched in 2005.

The paradigm shift in development strategy from the top-down approach to the endogenous bottom-up approach was centered around the promotion of regional innovative capacity. It was presumed that regional innovation capacity was fundamentally related to several factors: "building cooperative networks and stimulating the interaction between local authorities, the industrial sector, universities, R\&D agencies, financial institutes, and the other local non-governmental organizations" (Kim, 2009, p. 38).

Regional Policy and Decentralization together with Local Autonomy. The relations between regional even-development policy and decentralization policy are too complicated to define in a straightforward way. Theoretically, it may well absolutely be correct that decentralization policy is an integral component of regional even-development policy. According to this view, they are compatible with each other. The Noh administration combined regional even-development and decentralization, putting equal stress on both (Kim, 2005b).

The Noh administration created another presidential committee to oversee government innovation and decentralization. Decentralization strategies devised by this com- 
mittee were based on empirical data as to the most efficient way to distribute government functions and allocate financial resources between the central government and local governments. In addition, the governing capacity of local governments and the involvement of citizens in the local decision-making process were also taken into account (Kim, 2010a). The committee prepared a model of decentralization reform in 2004 that was seen as the most ideal form of decentralization reform to have been proposed in the political history in Korea (Kim, 2004). The legal foundation on which decentralization was built during the Noh's administration was the Special Act of Decentralization in 2003.

The committee's first order of business was a report outlining a five-year comprehensive decentralization action plan. It consisted of 47 specific tasks from seven broad policy categories related to decentralization reform that were expected to be completed by the end of 2008. Seven policy categories were "realigning authority between the central and local government, improving fiscal decentralization, promoting administrative independence of local governments, activating local legislation and improving election system, strengthening the accountability of local governments, activating civil society and establishing cooperative intra-governmental relationships" (Kim, 2010a, pp. 33-34).

Two significant objectives were achieved by the Noh administration's decentralization initiative. The first was asymmetrical decentralization in Jeju Island, off the coast of the Korean peninsula. More than 4,000 central functions were granted to Jeju Island so as to allow it to set up a special decentralized self-governing local government. It was significant that the powers that devolved to Jeju encompassed the ability to establish local law enforcement and to abolish local agencies of the central government that had overseen Jeju Island until then.

The second achievement of the decentralization initiative was an increased level of citizen involvement in local decision making. Debates on allowing referendums, recalls and taxpayer's suits had been held prior to the Noh's administration, but the central government had never taken any actions to adopt them During Noh's administration, they were introduced by turns.

The Noh administration also looked on local financial autonomy as a key element in decentralization. Several steps were taken during this period to promote the fiscal autonomy of local governments. These included increasing the level of general revenue sharing (up to 19\%), efforts to manage the national subsidy system in more efficient ways, and the creation of a special account for national even-development (Kim, 2010a).

During this period the political power of local governments had grown to the extent that the central government had to consult local governments in order to ensure 
that national policies were carried out. Without the support of local governments, the central government's national policies could not succeed. Quality of life became a national goal as well as local preference.

Regional Policy and National Development. The main features of regional policies in this era were decentralization and regional even-development. It was broadly recognized that local democracy could not be realized if local governments were not granted sufficient power. Accordingly, controversies over decentralization and regional evendevelopment were main issues in the presidential election in 2002. President Noh advocated decentralization and regional even-development during this presidential campaign and gave top policy priority to them when he was elected, contributing to different type of national development from that of previous eras.

\section{Regional Policy with Large-scale Economic Partnership since 2008}

Relationship between Regional Policy and Decentralization Policy between 2008 and the Present. At the end of Noh's presidency, another policy shift was introduced with respect to regional policy and decentralization, fundamentally changing tack by decoupling regional even-development from decentralization, which enabled them to be pursued independently with no mutual consideration.

Regional Policy between 2008 and the Present. Significant change in regional policy under the Lee administration is evidenced by the fact that the name of the presidential committee that had taken charge of handling regional policy under the Noh administration was changed from the Presidential Committee on National Even-development to the Presidential Committee on National Development.

In this vein, the Lee administration unsuccessfully tried to turn Sejong from an administration-centered city into business-centered city. This move came as no surprise, as Lee had previously been the mayor of Seoul city and strongly opposed the Sejong project. His administrative philosophy was more oriented to efficiency than equity. This philosophy was apparent in such national policy themes as "warm market economy," "vitalized market economy," and "small government" (Kim, 2010b).

The Sejong project was the most important symbol of regional even-development during the Noh administration, and so the Lee administration's attempt to change the direction of the Sejong project can be interpreted as an indication of a desire to eradicate regional even-development. The Lee administration's new business-centered proposal encountered stiff opposition from numerous regions outside the capital, even from lawmakers of the ruling party, and thus failed to secure from consent and approval by the Congress (Kim, 2012a).

The stunted progress in the development of Sejong resulted in the delayed completion 
of infrastructures, including buildings, offices, housing, and roads. Public officials who had begun to move to Sejong city in September 2012 experienced a lot of inconveniences due to a lack of facilities and infrastructures.

The Lee administration divided the regions up into three economic zones: the daily- life zone, the large-scale economic zone, and the mega-economic zone. The lower-tier governments corresponded to "the daily economic zone," for which a basic development plan was devised. The large-scale economic zone was proposed on the assumption that the existing administrative jurisdiction of upper-tier governments, namely, provinces and metropolitan cities, which used to be a main economic entity holding powers to manage regional policies, was not large enough. Two or three upper-tier administrative jurisdictions were merged into a mega-economic zone, which was empowered to coordinate large-scale projects in order to increase regional economic competition. These jurisdictions were related to constituent provinces or metropolitan cities at the same time. (Kim, 2010b).

The national government's aim was to pursue selective and concentrated regional development within the large-scale- and the mega-economic zones. A committee was established to coordinate efforts between the national government and the large-scale zone (Kim, 2009), but it lacked the necessary power and authority to effectively organize trans-frontier projects at the macro level.

A national policy that was closely related to the regional development was a project designed to revitalize the four major rivers. Despite strong criticism from numerous corners, including groups that worried about possibility of environmental destruction, Lee's administration gave the four rivers project top priority, firmly believing that the project could contribute considerably to regional development as well as to the efficient management of water. This project remained controversial, plagued during the Park Geun-hye administration by accusations of inappropriate construction, unlawful actions by contractors, and improper implementation.

Regional Policy and Decentralization together with Local Autonomy. Lee's administration was not active in efforts to devolve central authorities to local governments, as is suggested by the fact that even though a new legal framework for decentralization had been set up, it wasn't until six months later that the administration authorized the creation of committee to put the framework into effect.

The emphasis on administrative efficiency by the Lee administration was also reflected in the implementation of decentralization policy. For the purpose of promoting local governing capacity, Lee's administration had encouraged the local governments to consolidate, providing incentives for them to do so. During the first stage, the administration sought amalgamation of local governments on a voluntary basis. An example is the 2010 consolidation of three smaller cities to form big Changwon. 
To further encourage consolidation of local governments, the Lee administration prepared a special law on the reform of local administrative structures in October 2010. According to the law, a presidential committee on local administrative structural reform, which was replaced by a presidential committee on local autonomy development by the Park Keun-hye administration in 2013, was established. This committee made interim reports to the president in 2012 offering suggestions for carrying out local administrative structural reform and decentralization.

According to these interim reports, administrative structural reform of the metropolitan cities is the best way to improve urban competition in a globalized interdependent economy. The two-tier system of metropolitan governments in Korea suffers from numerous administrative problems due to the disparity in a level of public services, the imbalance in financial capacity, and the wide discrepancy in population among lower-tier governments within the metropolitan cities (Kim, 2013).

As in other countries, there were coordination problems between the lower-tier governments and the metropolitan governments in the process of implementing largescale projects involving more than two lower-tier governments. As an innovative solution to these problems, the report suggested switching the metropolitan governments from a two-tier to a single-tier system (Kim, 2010c), the idea being that single-tier metropolitan governments are more in harmony with the globalized interdependent economy (Kim, 2012b).

Local fiscal autonomy has been a primary concern for a long time. No doubt local governments should have sufficient resources to finance their operations in line with the expectations of their citizen, but the reality is that most local governments are heavily dependent on resources from the national government. The central government had been very reluctant to reform local finances in such a way as to strengthen local fiscal autonomy, but then, unexpectedly, the Lee administration introduced a local sales tax and local income tax, which should greatly contribute to local fiscal autonomy and enhance local financial capacity.

During this period, the institutional power of local governments did not significantly increase. Nonetheless, the voices of local governments continued to grow incrementally louder, as local governments sought to become partners of national governance.

Regional Policy and National Development. President Lee stressed economic development over local democracy. Regional policies were streamlined so as to improve national economic competitiveness and featured the introduction of a large-scale economic zone policy and attempts to change Sejong from an administration-centered city to business-centered city. 


\section{COMPARISON OF ANALYSES}

Each period analyzed in the previous sections manifested differentiated regional and decentralization policies. These are recorded in table 1.

As shown table 1, during the 1970s and 1980s regional policies were centered around regional economic development, and thus there was considerable need for local administrations to fall in line with central policy directions and mandates. It could be said that it was hard to resist maintaining a hierarchical relationship between the central government and local governments, given the usefulness of such a relationship in achieving rapid economic development in Korea. Together with rapid economic development, regional even-development raised many concerns, in particular, from the regions outside the capital. In the 1990s, establishing local autonomy became necessary as a way of improving democracy. Measures for establishing local autonomy were followed by decentralization reform in the late 1990s.

Among other things, the Noh administration was notably characterized by a

Table 1. Comparison of Policies in Each Period

\begin{tabular}{|c|c|c|}
\hline & Regional Policy & Decentralization Policy \\
\hline $70 s-80 s$ & $\begin{array}{l}\text { first comprehensive national development plan: } \\
\text { - regional economic policy } \\
\text { - industry location policy } \\
\text { - regional balanced development } \\
\text { Capital Regional Readjustment Act } \\
\text { second comprehensive national development } \\
\text { plan: } \\
\text { - regulation over the capital region } \\
\text { - special emphasis on rural regions }\end{array}$ & $\begin{array}{l}\text { local administration } \\
\text { hierarchical structure between } \\
\text { national local governments } \\
\text { Saemaeul movement }\end{array}$ \\
\hline $90 \mathrm{~s}$ & $\begin{array}{l}\text { third comprehensive national development plan: } \\
\text { - regional even-development } \\
\text { - regional center city policy } \\
\text { - new industrial center policy } \\
\text { - regulation over the capital regions }\end{array}$ & $\begin{array}{l}\text { local autonomy policy } \\
\text { local council and elected CEO } \\
\text { delegation of central functions } \\
\text { to locality }\end{array}$ \\
\hline 2003-2007 & $\begin{array}{l}\text { national even-development plan } \\
\text { - comprehensive approach to even-develpment } \\
\text { - dispersal of public agencies and offices: } \\
\text { innovation cities } \\
\text { - regional innovative capacity } \\
\text { - Sejong project }\end{array}$ & $\begin{array}{l}\text { decentralization } \\
\text { five year comprehensive } \\
\text { decentralization action plan }\end{array}$ \\
\hline 2008-now & $\begin{array}{l}\text { fourth national development plan } \\
\text { large-scale economic zone policy }\end{array}$ & $\begin{array}{l}\text { local sales tax } \\
\text { local administrative structural } \\
\text { reform structural change in } \\
\text { metropolitan city }\end{array}$ \\
\hline
\end{tabular}


distinctive policy of regional even-development and decentralization, for which two separate presidential committees were established to realize. The Presidential Committee for National Even-development designed regional even-development policies, features of which included dispersal of public agencies and offices in 11 innovation cities, improvement of regional innovative capacity, and the Sejong project. The Presidential Committee for Government Innovation and Decentralization came up with a comprehensive decentralization reform plan.

Under the Lee administration, regional even-development and decentralization reform was not emphasized as much. Several reform measures, including the creation of large-scale economic zones, the introduction of local sales tax, and the amalgamation of local governments were implemented incrementally.

\section{IMPLICATIONS AND CONCLUSION}

\section{Implications of the Changing Intergovernmental Relationship from Korea}

It has been generally accepted that a hierarchical relationship between the central government and local governments is a main factor determining the attainment of national goals because local governments act as implementing organs of the national policies that the national government formulates. This is the case in Korea, too.

Korea adopted a hierarchical relationship between the central government and local administrations in order to encourage rapid economic development by improving administrative efficiency. Local administrations with no political discretion were compelled to carry out national mandates to the letter.

In the wake of economic development over time and growing local democracy, the national government began to recognize local administrations as local governments endowed with a certain level of autonomy. Local governments work as local political entities that determine local policies and have their voices heard in the process of national policies. Consultation and dialogues between the central government and local governments replace mandates and directives issued by the national government. Nowadays, local governments in Korea are partners in national governance, playing an important role in the process of national policy. The Korean case provides a model for developing countries, suggesting the kind of relationship between the central government and local governments that is required given certain national goals and circumstances.

The regional policies discussed in this paper are to a large extent attempts to generate a proper relationship between the central government and local governments. In light of different political and economic circumstances, regional policies have been amended, 
resulting in a relationship between the central government and local governments that enables the country to achieve national goals in an efficient and effective way.

\section{CONCLUSION}

This paper has analyzed regional policy since the 1970s. Each period taken up in this study has its own characteristics. The period between 1970s and 1980s featured a highly centralized system in which local administrations were effective in following central directives and mandates. Central regional policy during the first stage focused on industry location policy. This was followed by efforts to regulate the population of the capital region in order to prevent an overflow into it. SMP was one of the important regional policies that sought to address rural poverty under Park's administration.

In the 1990s, under Kim Young-sam's and Kim Dae-jung's administration, regional even-development represented regional policy, and decentralization policy came to underpin regional policy. The Noh administration in particular was active in developing regional even-development policies and decentralization policy at the same time. Under the Lee administration, the nature of the regional policy pursued by the Noh administration went from equity oriented to efficiency oriented.

This study indicates that regional policy in Korea has been distinct across the various administrations. In other words, changes in presidential leadership led to significant shifts in regional policy.

There are, nonetheless, also some common features of regional policy such as the emphasis on regional even-development. The importance of decentralization has been not ignored, and unless something unexpected happens, a similar policy theme will continue to inform the contemporary government.

\section{REFERENCES}

Assembly of European Unions. 2006. Regionalism across Europe. Strasbourg: Assembly of European Unions.

Cho, Y., and J. Joh. 1988. Urbanizing the rural economy of Korea: The central government policies to develop industries in rural areas. Asian Journal of Public Administration, 10(2): 175-193.

Eom, S. 2009. Mobilization and participation: The role of local public officials in the process of Saemaeul Undong. Korean Public Administration Review, 45(3): 97-122. 
Eom, S. 2011. The rural Saemaeul Undong revisited from the perspective of good governance. Korean Journal of Policy Studies, 26(2): 17-43.

Hwang, Y. 2006. Reexamination of rural Saemaeul Undong. Research on Agricultural History, 5(2): 17-53.

Kim, E., and J. Kim. 2007. A study of the economic effects of regulatory reform in the capital region in Korea. Suwon: Kyunggi Research Institute.

Kim, K. 2008. Redefining the goal and strategy of regional development policy in Korea. Retrievable from www.kdi.re.kr.

Kim, S. 1997. Issues and tasks of local autonomy in Korea. Busan: Jinyoung Moonhwasa.

Kim, S. 2004. Governmental innovation and decentralization reform. Local Government Studies Review, 8(1): 151-176.

Kim, S. 2005a. Realities and implications of local governance in Korea. Korean Journal of Local Government Studies, 8(4): 73-98.

Kim, S. 2005b. An assessment of decentralization and its tasks: A critical view of the national even-development policy and decentralization. Korean Journal of Governance Studies, 12(2): 95-133.

Kim, S. 2006. Intergovernmental relationships between the Seoul city government and the central government and others. Paper presented at the conference of the Korean Association of Local Autonomy Studies.

Kim, S. 2010a. An analysis and evaluation of the regional policies of President Lee Myung-bak. Paper presented at the conference organized by the Korean Association for Public Administration.

Kim, S. 2010b. Evolution of decentralization in Korea from intergovernmental relations perspectives. In T. Im (ed.), Decentralization and development (pp. 00-00). Seoul: Seoul National University Press.

Kim, S. 2010c. A comparative study of the decentralization policies of the Noh Moohyun and the Lee Myung-bak administrations. Paper presented at the conference of the Korean Association for Local Government Studies.

Kim, S. 2012a. Sejong city policy. In Osung Kwon (ed.), Performance and tasks of major policies in the Lee Myung-bak administration (pp. 00-00). Seoul: Korean Institute of Public Administration.

Kim, S. 2012b. A study of factors affecting competitiveness of local governments. Korean Journal of Public Administration, 50(3): 67-98.

Kim, S. 2013. Debates on the structural reform of metropolitan cities. Korean Journal of Local Government Studies, 16(4): 55-77.

Kim, Y. 2000. An evaluation of regional development policy in Korea. Paper presented at the international conference on regional development strategies and implementation organized by OECD-Chollabuk-do and KRIHS. 
Kim, Y. 2009. Spatial changes and regional development policy in Korea. Paper presented at HNU-QUT joint workshop on regional development in Korea, coorganized by Hanbat University and CDI.

Korea Research Institute for Human Settlements. 2005. Tasks of national even-development under deconcentration and decentralization. Anyang: Korea Research Institute for Human Settlements.

Korean Research Institute for Local Government. 2013. Regional development policy. www.krila.re.kr.

Ministry of Construction and Transportation. 2006. National land affairs. Seoul: Ministry of Construction and Transportation.

Noh, W. 2013. Saemaeul Undong in Korea. Seoul: Bubmoonsa.

Park, S. 2009. Analysis of Saemaul Undong: A Korean rural development program in the 1970s. Asia-Pacific Development Journal, 16(2): 113-140.

So, J. 2009. Regional governance and Saemaeul Undogn in Korea. Korean Journal of Local Autonomy Studies, 59(3): 93-112.

Ueta, H., and T. Meitake, eds. 2001. Regional development. Tokyo: Gyousei.

Whang, I. 1983. Innovations in local administration for rural development in Korea. Journal of East and West Studies, 12(2): 1-22. 